\title{
ORGANIZATIONAL POLITICS AND CHANGE: A CONCEPTUAL MODEL AND EMPIRICAL TESTING*
}

\author{
Monika Kulikowska-Pawlak**
}

\begin{abstract}
Firms increasingly embed organizational politics in their change management but struggle to effectively manage it. To better understand how they do so, I have built and tested a conceptual model using data from 158 small and medium-sized Polish enterprises. The results show relationships between organizational politics, change management, and organizational effectiveness. The findings extend and specify the understanding of organizational politics as a driver of organizational change success.
\end{abstract}

Keywords: organizational politics, change management, organizational effectiveness.

\section{INTRODUCTION}

Currently, in the area of management sciences, the awareness of the crucial role of power and its application in organizational processes is growing rapidly (Ferris \& Treadway, 2012). Against this backdrop of a general trend, research interests focus on organizational politics as a specific meaning given in connection with strategic change (Gioia \& Chittipeddi, 1991; Mantere et al., 2012). However, empirical research into the role of organizational politics in change management is extremely scarce. This article aims to fill this gap.

The content of the study is contained in four basic parts. Firstly, based on the critical review of the relevant literature, the theoretical basis for studying the role of organizational politics in organizational

\footnotetext{
This study was conducted within the framework of a research project funded by the National Science Centre (grant no 2013/11/B/HS4/00673).

** Uniwersytet Ekonomiczny w Katowicach. E-mail: monika.kulikowska-pawlak@ue. katowice.pl
} 
change management was described. Secondly, the conceptual model was built and research hypotheses were formulated. Subsequently, the model developed was tested empirically on a sample of 158 small and medium-sized enterprises operating in Poland. Finally, the theoretical and practical implications of the model tested were shown and the main directions for further research were suggested.

\section{ORGANIZATIONAL POLITICS}

The process of organizational politics can be viewed from many perspectives. The paper acknowledges that the best one will be a resource-based approach to strategic management. A part particularly useful in this regard is the part of a strategic approach that refers to the dynamic capabilities of the organization. Bibliometric analysis and content analysis allowed the discovery of an intellectual core of research into the domain of dynamic capabilities (Di Stefano et al., 2009). It turned out that the theoretical roots of the dynamic capabilities of the organization lie first and foremost in the resource-based approach to strategic management, and partly in looking through the prism of knowledge, evolutionary economics, the behavioral theory of the firm, or transaction costs. The nature of these capabilities lies in facilitating the development of new activities or enhancing the existing ones, in order to turn to opportunities and to adapt to the changing determinants of competitive advantage. I think that dynamic capabilities are closely related to both organizational resources and organizational politics. My core research goal emerges against this backdrop, which aims to explain the role of organizational politics in shaping a company's competitive advantage.

Following earlier definitions (Cropanzano et al., 1995), I propose that organizational politics is the phenomenon expressed in attempts to exert a social influence on people who can be a source of benefit used to support and protect the interests of the entity exerting the influence. Following these ideas, I propose working definition of organizational politics: (1) an exercise and use of power and influence that primary occurs outside of formal organizational processes, systems, routines and practices, (2) based upon influence tactics designed to further self and / or organizational interests, (3) aimed at reconciling potentially competing interests, (4) strategic and focused on achievements, 
(5) approach that has at its core a belief in a positive vision of the organization's future. This definition increases the opportunity to view the organizational politics as a force for organizational effectiveness, as a way to influence organization's positively and bring about productive change.

Another important assumption is understanding organizational politics as an organizational process of sensemaking. Sensemaking and improvisation seem to be an effective behavioral strategy for making change (Cunha \& Cunha, 2003), especially in dynamic conditions. In the rapidly changing environment, organizations launch a strategy of innovation from a broadly shared, though vague, strategic intent that creates a framework for sensemaking and improvisation (Wood, 2007). Taking into account the above, I have chosen a definition by Sederberg (Sederberg, 1984) from among the many definitions of organizational politics, which describes organizational politics as a behavior for "creating, sustaining, modifying, and abandoning shared meanings" (Sederberg, 1984, p. 7). In this study I am trying to present the consequences of such a methodological outlook and to specify the content of organizational politics as an organizational process of sensemaking.

Organizational sensemaking is when organization participants support a specific point of view and try to affect the understanding of reality by other participants in the organization through the various tactics of influence. As a result, inter-subjective sense constructed socially appears. An integral part of this sensemaking process is action (Weick, 1988). In short, action is used as a basis for new sensemaking, while simultaneously, it delivers feedback on the sense already established (Rudolph et al., 2009). Therefore, organizational sensemaking is clearly political (Clark \& Geppert, 2011). It should be noted that in previous research, organizational creativity and entrepreneurship were linked as important processes supported by sensemaking (Drazin et al., 1999; Jay, 2013).

Organizational politics is an important adaptation mechanism in the conditions of organizational ambiguity (Ferris \& Hochwarter, 2011) because the information gained through political behavior reduces the uncertainty faced by company's employees. In particular, active influence exertion leads to the creation of meanings and sensemaking (Hope, 2010), which are considered to be the aspects of politics processes (Maitlis \& Lawrence, 2007), affecting the interpretations and formation 
of normative behavior (Ammeter et al., 2002). Few empirical studies show that the creation of meanings by managers increases the positive effects of the implementation of change (Hope, 2010), helps overcome resistance to change (Buchanan, 2008), and also extends shared beliefs and builds social consensus (Silvester, 2008).

Various conceptualization of organizational politics has been suggested, but most have treated organizational politics as a uni-dimensional construct, arguing that positive organizational politics is a low-level reflective latent variable model. To avoid the omission of explicitly specifying the higher - order dimensionality of the focal construct - a key factor contributing to the misspecification of measurement models in strategic management research (Podsakoff et al., 2006) - I hypothesized that organizational politics is type II (reflective - formative) hierarchical latent variable model (Becker et al., 2012).

\section{THEORETICAL BASIS FOR EXAMINING THE ROLE OF ORGANIZATIONAL POLITICS IN ORGANIZATIONAL CHANGE MANAGEMENT}

Recently Cannella and Ocasio (2014) have highlighted an important role that organizational politics plays in strategic processes such as strategy formulation and implementation. The concentration of formal and informal power in the hands of management teams has a strong influence on decision-making, and is a key reason for strategic change (Greve \& Mitsuhashi, 2007).

The starting point for the discussion is the strategy as practice approach to the implementation of the strategic process and the praxis, i.e. the flow of activities, enabling the strategy implementation (Stańczyk-Hugiet, 2014). The growing number of studies in this trend (Jarzabkowski, 2005; Vaara \& Whittington, 2012) emphasize the important role of power relations between organization participants, who often have divergent interests (Hardy \& Thomas, 2012; McCabe, 2010; Rasche \& Chia, 2009). These studies draw attention to power as a key element in the formation and renewal of strategic practice, and they abandon a process-based approach to strategy that changes over time, as well as the understanding of power as a productive force (Ezzamel \& Willmott, 2008). In other words, strategic practice is 
renewed through both power relations developing strategic practices and through resistance. An important attribute of this process is the holistic approach to strategy empowerment, as a result of recognizing the perspective adopted by an organization participant as strategic. In this respect, strategy is understood as a point of reference for organizational reflection, allowing strategic power relations to emerge.

The way of thinking mentioned refers to the works by prominent theoreticians of sociology such as Foucault (1977) and Bourdieu (2002), who use relational ontology and treat strategy in terms of the formation and renewal of power relations by means of various types of discursive and non-discursive practices (Halford \& Leonard, 2006). Thus, a crucial argument in favor of the post-structural approach to strategy as practice is to assume that strategic practice is historically, socially and politically embedded (Chia \& Holt, 2006). According to Foucault (1977), practice is the established way of formulating statements in discourse; it means that discourse takes the form of various practices, and these practices are governed by some other discursive practices (e.g. a collection of anonymous, historical regulations that are always determined by time and space). Thus, discursive practices define what, how, when, and on what basis an organization participant is able to say something.

Social practices perform the function of a common denominator in the process of empowerment, where various discourses and entities are located within a wider network of historical and spatial relationships. Therefore, discursive practice is not only a linguistic phenomenon but it is related both to social power relations as well as non-discursive practices and institutional constructs (Carter et al., 2008). As a consequence, the practices are historically and socially determined ways of thinking and conceptualizing within power relations (Laine \& Vaara, 2007).

More specifically, strategic discursive and non-discursive practices, continuously forming and renewing strategic practice cannot be detached from power relations. Such a relational view of power leads to treating power as a force generating strategic practice and to taking into account not only management staff but also all participants in the organization. These practices highlight legitimized perspectives and build norms for developing the theory of action, while necessary constraints involve the simultaneous application of power and provocation to resistance. This is the reason why instead of focusing attention on the one-dimensional effects of different practices, it is necessary to look at empowerment 
as a link between the different ends of strategic practices. Strategy is updated on the spot because organization participants introduce different discourses and also oppose other discourses. All this happens in the context of power relations.

The core of Foucault's logic (Foucault, 1978) is to analyze social phenomena such as strategy by means of power relations, where power is understood as a productive force that creates and modifies a given social phenomenon. Power is never unidirectional; it always includes the ability for an organization participant to behave differently, it emerges in modifying the ability of organization participants to think and act in different situations (Alhanen, 2011). Moreover, power modifies, strengthens and radically transforms power relations as a result of endless conflicts and conflicts of interest. Real power is hidden and updated in resistance. Thus, organization's strategy is developed in a constantly renewing network of power relations and therefore it should be explored in relation to the dominant discourse and practices that oppose this discourse. This self-reliant relationship between the dominant discourse about strategy and organizational resistance is a context of strategic practice.

Organizational strategy emerges in strategic guidelines, procedures and operational activity (McKinlay et al., 2010). It is contained in the managerial discourse, especially the philosophical, moral and philanthropic statements in the mission and vision of the organization. Its creation is nothing but the non-linear creation and modification of new organizational reality through discursive and non-discursive practices, and especially through the process of empowerment and identification. In the process of empowerment, organization participants position themselves in relation to strategy. Then they conduct personal narratives to establish their identity, thus negating the narratives of other participants. The diverse positions of the participants in the organization form an organizational network of power relations within which practices are implemented. In short, the strategic discourse has no single source, and it is not one-subject. Within the organizational platform of power relations, discursive and non-discursive strategic practices are implemented that legitimize the existence of the organization. In this sense, strategic practice is a kind of strategic power play between organization participants promoting their interests.

The relational ontology of strategic practice presented can be used as a methodological perspective for updating organizational change. 
First and foremost, the design of change as a specific strategy diversifies organization participants into supporters and opponents conducting the discourse on organizational change. Such discourse occurs within an existing and changing platform of power relations. Change supporters use organizational practices that increase the likelihood of its implementation. Change opponents use the practice of organizational resistance obstructing change. Moreover, the plan of organizational change is a reference point for positioning organization participants who seek their identity as the subjects of the proposed transformations.

It should be noted that most research was conducted in the context of making organizational changes. It was found that management staff can actively influence the implementation of change in the context of power relations and conflicts of interest, negotiation and political maneuvering involving diverse actors (Crozier \& Friedberg, 1982). The mobilization of coalitions supporting the change plays a particular role in this case (Buchanan \& Badham, 1999; Kanter \& Stein, 1992), as well as the political distribution of meaning (Sonenshein, 2010). In short, organizational politics defined as behaviors aimed at "creating, sustaining, modifying, and abandoning shared meanings" (Sederberg, 1984 ) is a critical process determining the success of organizational change.

\section{A CONCEPTUAL MODEL AND RESEARCH HYPOTHESES}

The critical review of the relevant literature is a good basis for conceptualizing the political aspects of organizational change. Figure 1 shows fundamental relationships between the three key theoretical constructs. First of all, the relationship between organizational change management and organizational effectiveness has been shown. In addition, the relationship between organizational politics and organizational effectiveness has also been presented. Finally, the moderating role of organizational change management has been emphasized.

The conclusion is that considering organizational changes, power relations should be taken into account that shape the formulation and implementation of the project. In fact, there is no power without resistance. Organizational resistance is never external to a change project and is only one element of a key contradiction in making changes. 
Practically speaking, this means that change should be considered bi-directionally - in terms of the prevailing organizational discourse and through the prism of recognizing resistance points. Thus:

Hypothesis 1: Organizational change management is positively related to organizational effectiveness.

Taking into account the formative nature of the concept of organizational change management and its two dimensions, two sub- hypotheses should be formulated:

Hypothesis 1a: The social dynamics of organizational change is positively related to organizational effectiveness.

Hypothesis $1 b$ : The adaptability of organizational change is positively related to organizational effectiveness.

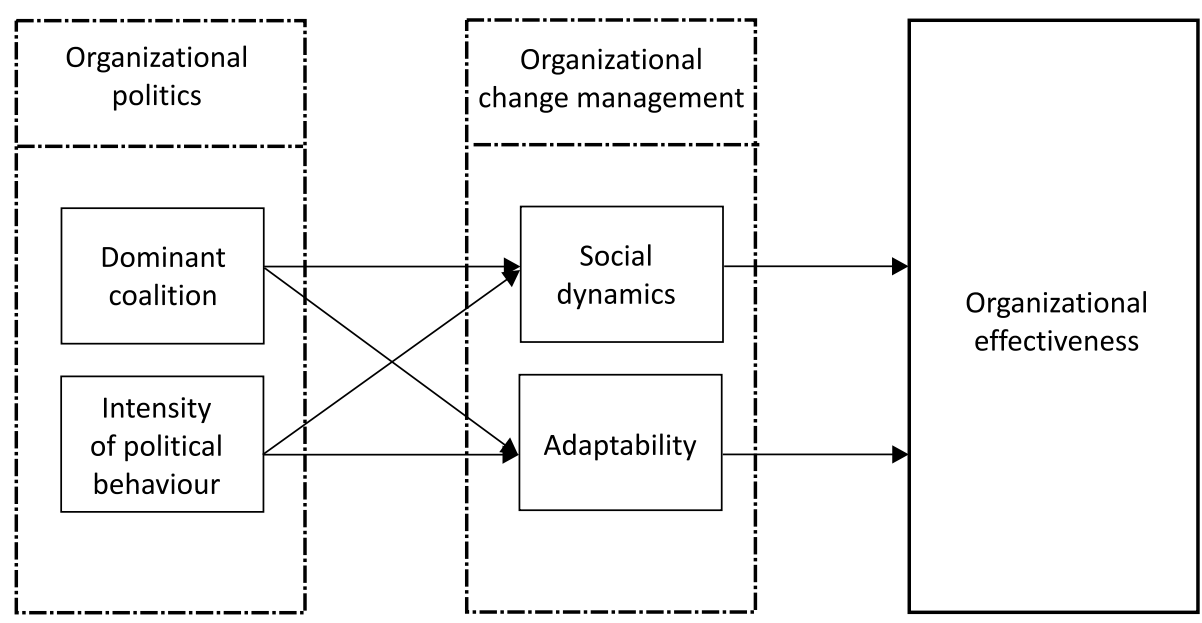

Figure 1. Research model

Source: own study.

The above discussion indicates that a political dimension is a key aspect of any organizational change, and organizational politics is the core of the change process. Consequently, this leads to the following hypotheses:

Hypothesis 2: Organizational politics and change management positively co-exist.

The two dimensions of organizational politics were distinguished and the two dimensions of organizational change management already identified are the basis for formulating four sub-hypotheses: 
Hypothesis 2a: The occurrence of a dominant coalition is positively correlated with the social dynamics of organizational change.

Hypothesis $2 \mathrm{~b}$ : The occurrence of a dominant coalition is positively correlated with the adaptability of organizational change.

Hypothesis 2c: The intensity of political behavior is positively correlated with the social dynamics of organizational change.

Hypothesis 2d: The intensity of political behavior is positively correlated with the adaptability of organizational change.

The last hypothesis says about the regulative role of organizational change management in the relationship between organizational politics and organizational effectiveness. The specific formulation of this hypothesis is as follows:

Hypothesis 3: Organizational change management plays the role of a moderator of the relationship between organizational politics and organizational effectiveness in such a way that it strengthens this relationship.

The two-dimensional nature of organizational politics leads to four further sub-hypotheses:

Hypothesis 3a: The social dynamics of organizational change acts as a moderator of the relationship between the dominant coalition and organizational effectiveness in such a way that it strengthens this relationship.

Hypothesis 3b: The social dynamics of organizational change acts as a moderator of the relationship between the intensity of political behavior and organizational effectiveness in such a way that it strengthens this relationship.

Hypothesis 3c: The adaptability of organizational change acts as a moderator of the relationship between the dominant coalition and organizational effectiveness in such a way that it strengthens this relationship.

Hypothesis 3d: The adaptability of organizational change acts as a moderator of the relationship between the intensity of political behavior and organizational effectiveness in such a way that it strengthens this relationship. 


\section{METHODOLOGY AND THE FINDINGS OF EMPIRICAL RESEARCH}

In order to test the research hypotheses and a model, quantitative research was conducted among companies from Poland. The Research and Expertise Center at the University of Economics in Katowice was responsible for technical data collection by means of a questionnaire.

Research conducted at the turn of 2011 and 2012 covered 158 small and medium-sized enterprises in Upper Silesia. A survey was used as a basic tool for obtaining empirical data. The target group for field research was top management. The selection of managers as respondents was due to the fact that the variables used in research required information to be provided by people who had good knowledge of the overall functioning and development of the organization (a detailed method of sample selection see Bratnicki, Kulikowska and Dyduch (2004). Lower-level managers do not have such knowledge (Kreiser et al., 2011). Higher-level managers responded to questions listed in a questionnaire, and there were pollsters sent to each randomly selected company that agreed to participate in a research. In order to test a research model and the related hypotheses, a survey was used, in which information was collected through personal interviews (Babbie, 2011), using the relevant questionnaire. Thus, a specific survey method was used, which is one of the most commonly used research methods in social sciences (Leon-Guerrero \& Frankfort-Nachmias, 2015).

While this paper is a part of a larger study, I briefly describe only variables related to the research model created in this particular study. Thus, the questionnaire was composed of three main parts, related to organizational politics, organizational change management, organizational effectiveness measures. In the following part I concisely describe each measure. When designing empirical research, organizational effectiveness was measured through the subjective assessments of competitive advantage. The company's competitive advantage was assessed using a scale whose psychometric properties had been tested in previous empirical research (DeVellis, 2003). The measurement of organizational effectiveness was based on the scale of ten issues, for example "The average growth of market share in the last three years." Respondents were asked to rate organizational effectiveness 
compared to competitors using the following scale: 1 - definitely worse, 2 - worse, 3 -rather worse, 4 - almost the same, 5 - somewhat better, 6 - better, 7 - definitely better (Zbierowski et al., 2014).

Two further constructs, organizational change management and organizational politics, were operationalized using a seven-point Likert scale, from 1 - I strongly disagree to 7 - definitely agree. A tool for measuring organizational change management was the operationalization of the behavioral dimension of entrepreneurship landscape, tested in organizations of various sizes operating in Poland (Bratnicki et al., 2004). The whole research tool covers six issues that make up two factors. The first factor, the social dynamics of organizational change (Cronbach's a $=932$ ), covers four issues, for example "Organizational changes are partial modifications that gradually streamline current business." The second factor is the adaptability of organizational change (Cronbach's a $=771$ ), covering two issues, for example "The organization adjusts its capabilities and opportunities in the environment to maintain the ability to transform strategies and to create new sources of competitive advantage."

The eight-point scale developed by Kacmar and Ferris was used to measure organizational politics. Based on the empirical data obtained, factor analysis was conducted to identify two dimensions. The first one called the dominant coalition (Cronbach's a $=715$ ) is made up of two issues, for example "There is a group in my organization that always achieves its goals", another six issues build up the intensity of political behavior (Cronbach's a $=923$ ), for example "In my organization, information is usually obtained, provided that you know the right person who has this information."

Three controlled variables were also introduced in research. The first one is the period of existence of the enterprise, measured by the number of years since its foundation. The second control variable is the size of the organization measured by the number of employees and the value of total assets. The industry in which the company operates was also taken into consideration.

The findings of empirical research obtained prove the hypothetical assumption that organizational change management positively correlates with organizational effectiveness. This statement refers to the hypothesis H1a about the relationship between the social dynamics of organizational change and organizational effectiveness $(r=0.277$; $p=0.00$ ). This is also the case with the hypothesis $\mathrm{H} 1 \mathrm{~b}$, which describes 
the relationship between adaptability of organizational change and organizational effectiveness $(r=0.331 ; p=0.00)$.

The findings of empirical research obtained prove that there is the relationship between organizational politics and organizational change management. However, contrary to expectations, this relationship is negative in terms of the dominant coalition, both as regards the social dynamics of organizational change $(r=-0.533, p=0.00)$ and the adaptability of organizational change $(r=-0,392, p=0.00)$. This means the falsifications of hypotheses $\mathrm{H} 2 \mathrm{a}$ and $\mathrm{H} 2 \mathrm{~b}$. However, the assumptions about the relationship between the intensity of political behaviour and the social dynamics of organizational change $(r=0.491$, $p=0.00)$ and the intensity of political behavior and adaptability of organizational change $(r=0.339, p=0.00)$ were proven. Thus, the hypotheses $\mathrm{H} 2 \mathrm{c}$ and $\mathrm{H} 2 \mathrm{~d}$ were verified.

The results of organizational change management as a moderator of the relationship between organizational politics and organizational effectiveness do not prove hypothesis 3 (see Table 1.). The condition of moderation is fulfilled solely for the social dynamics of organizational change with respect to the dominant coalition, as illustrated by model $3 \mathrm{a}$ in Table 1 . Hypothesis $3 \mathrm{a}$ was proven, although the fundamental dependence, contrary to expectations, is inversely proportional. In other words, the social dynamics of organizational change reinforces the negative relationship between the dominant coalition and organizational effectiveness. It should be noted that the size of the enterprise has the positive impact in this regard $(r=0.262, p=0.002)$. The other sub-hypotheses $(\mathrm{H} 3 \mathrm{~b}$, $\mathrm{H} 3 \mathrm{c}$, and H3d) about the moderating role of organizational change management were falsified.

\section{CONCLUSION}

Willingly or unwillingly, members of organizations engage in political debates. These debates are either fruitful for the wellbeing of the organization, or destructive in this regard (Miller et al., 2008). The debate in the field of organizational politics, albeit gaining attention, still focus on the negative aspects of this phenomenon (Sonaike, 2013). My study sheds light on positive sides of politics, also for organizational effectiveness. 


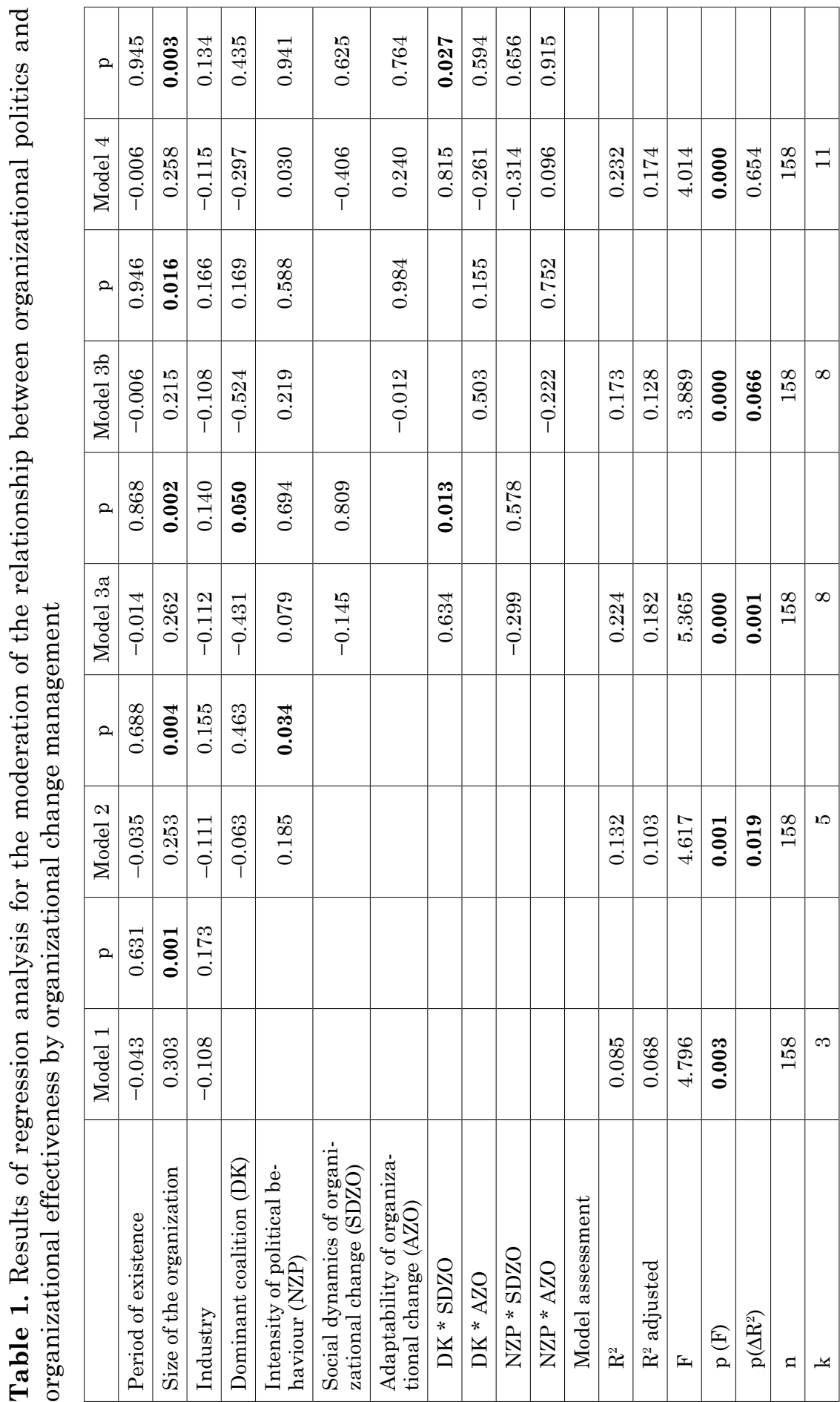

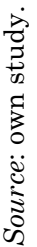


This however brings us to conclusion that organizational politics shall not be studied in isolation. As for any good theory, explicating relationships and illustrating them with data brings little knowledge to the field. What really ads value are mechanisms allowing for certain relationships to exist. Thus, at the conceptual level I decided to enrich my initial research model with such a mechanism - it is organizational change management. Organizational change management has a significant impact on organizational effectiveness achieved by the company. The relationship between organizational politics and organizational change management observed as a result of empirical research requires the introduction of political aspects into the theory of organizational change. In other words, organizational politics should be an inalienable element of any change management concept.

This finding also opens a space for a broader discussion. Especially, about other contingent variables and organizational phenomena that would influence the relationship between organizational politics and organizational performance. So far, researchers have stressed the importance of organizational context (Burgelman, 2002). Thus, for future research I propose that it would be beneficial for deeper understanding of organizational politics dynamics to introduce two other mechanism, namely strategic political management (see: Oliver \& Holzinger, 2008), and strategic design, perceived as organizational culture and organizational structure (Bilton \& Cummings, 2010; Damanpour \& Aravind, 2012) in the following research.

\section{DISCUSSION}

From a practical point of view, one should pay attention to the negative influence of concentrating the power in the hands of the dominant coalition on the success of organizational changes. While managing such changes, it is a good idea to consider the reasons for improvement. Organizational politics should be favorable to making sense of this activity and maintaining its activity even in disruptive and discouraging situations. The passivity of the workers, or taking the easy way out, are undoubtedly barriers to facing the organizational reality that is truly realized by the responses that this reality gives to our action.

The results of the research conducted allow us to formulate some guidelines for managerial practice. Managers seeking to increase firm 
competitiveness through entrepreneurship should create conditions conducive to political behavior such as: (a) using key managers to support initiatives, mobilize support or opposition to organizational strategies, policies and practices; (b) seeking to achieve autonomy of action enabling experimentation and the stimulation of the bottom-up change; (c) referring to superior objectives, common values and ideals to inspire specific behavior of others; (d) questioning the perception of organizational reality so as to go beyond the existing state of affairs; (e) striving to determine what sense to give to new events.

Generally speaking, when designing a change-focused company, you need to bear in mind that you need to prepare your employees for tasks that have to deal with ambiguous situations and for which no procedures have been established yet. The way in which a company is organized has to emphasize the large role of self-control supported by employees' independence, so that sensitivity to the realities of the business is ensured as well as sufficient freedom to take advantage of surprises, discontinuities, and discrepancies within the overall priorities.

Considering the broader context of relationships between organizational politics and organizational effectiveness we also perceive a chance of improving our understanding of dynamics of these relationships taking under consideration environment characteristics, namely dynamism, hostility and complexity (Sharfman \& Dean Jr, 1991). I strongly believe that enriching the research model would help to explain more variance in the organizational effectiveness. There is also a methodological implication flowing from the research. In particular, organizational politics are hard to observe and quantify. I strongly believe that carefully crafted qualitative research would greatly increase our understanding of currently hidden mechanisms allowing organizational politics to influence organizational performance. In particular, in-depth case study would allow to understand reasons and conditions under which relationships exist.

The scientific achievements presented also have certain weaknesses, which at the same time set the direction of fruitful future research. First of all, there is undoubtedly the need to expand the research sample to large companies. It would also be worth taking steps towards a more positive understanding of organizational politics, which entails the need to create a new scale for this theoretical construct. A condition for drawing justified conclusions is, in addition to affirming the co-occurrence of the cause and effect, making sure that 
the cause precedes the effect. My empirical research fulfills the first condition. However, to exclude the inverse relationship, longitudinal studies are necessary. Finally, it would be valuable to abandon the one-dimensional understanding of organizational effectiveness, so as to take into account, in addition, objective financial effectiveness, social effectiveness, or appropriation of value.

To my knowledge the paper addresses issues rarely undertaken in the literature. Neither organizational politics nor organizational change management has attracted significant research attention in the past. Thus, I empirically test and validate created scales allowing for measurement of these two phenomena. The mushrooming literature on high performance organization argues that a viable organization is key to organizational health (De Smet et al., 2007). In particular, I think that organizational members and the organization as a whole seek to reconcile different interests, view- points, and controversies by organizational politics and involves the application of human energy to the development of something new - and that creates some kind of value. In other words, organizational politics is the proactive component of organization's survival and growth. It challenges the conventional wisdom that politics has a destructive power for organizational effectiveness.

\section{REFERENCES}

Alhanen, K. (2011). Practices and Thought in Michel Foucault's Philosophy. Helsinki: Gaudeamus Helsinki University Press.

Ammeter, A.P., Douglas, C., Gardner, W.L., Hochwarter, W.A. \& Ferris, G.R. (2002). Toward a political theory of leadership. The Leadership Quarterly, 15, 751-796.

Babbie, E.R. (2011). The Basics of Social Research. Wadsworth: Cengage Learning. Becker, J.-M., Klein, K. \& Wetzels, M. (2012). Hierarchical latent variable models in PLS-SEM: Guidelines for using reflective-formative type models. Long Range Planning, 45, 359-394.

Bilton, C. \& Cummings, S. (2010). Creative Strategy: Reconnecting Business and Innovation. Oxford: Blackwell.

Bourdieu, P. (2002). Outline of a Theory of Practice. Cambridge: Cambridge University Press.

Bratnicki, M., Kulikowska, M. \& Dyduch, W. (2004). Organizational Entrepreneurship-Scope and Performance: The Model and Its Empirical Test. St. Andrews: British Academy of Management. 
Buchanan, D. \& Badham, R. (1999). Power, Politics, and Organizational Change. London: Sage.

Buchanan, D.A. (2008). You stab my back, I'll stab yours: Management experience and perceptions of organization political behaviour. British Journal of Management, 19(1), 49-64.

Burgelman, R.A. (2002). Strategy Is Destiny: How Strategy-Making Shapes a Company's Future. New York: The Free Press.

Cannella, A. \& Ocasio, W. (2014). The power of power: The role of power and politics in strategy process. Interests group panel. The paper presented at Annual Conference Strategic Managent Society in Madrid.

Carter, C., Clegg, S.R. \& Kornberger, M. (2008). SAP zapping the field. Strategic Organization, 6, 83-99.

Chia, R. \& Holt, R. (2006). Strategy as practical coping: A Heideggerian perspective. Organization Studies, 27(5), 635-655.

Clark, E. \& Geppert, M. (2011). Subsidiary integration as identity construction and institution building: A political sensemaking approach. Journal of Management Studies, 48(2), 395-416.

Cropanzano, R., Kacmar, K.M. \& Bozeman, D.P. (1995). Organizational politics, justice, and support: Their differences and similarities. In: R. Cropanzano \& K.M. Kacmar (eds.), Organizational Politics, Justice and Support: Managing Social Climate at Work (pp. 1-18). Westport, CT: Quorum Books.

Crozier, M. \& Friedberg, E. (1982). Człowiek i system: Ograniczenia działania zespołowego. Warszawa: PWN.

Cunha, M.P. \& Cunha, J.V. (2003). Organizational improvisation and change: Two syntheses and a filled gap. Journal of Organizational Change Management, 16(2), 169-185.

Damanpour, F. \& Aravind, D. (2012). Organizational structure and innovation revisited: From organic to ambidextrous structure. In: M.D. Mumford (ed.), Handbook of Organizational Creativity (pp. 483-451). London, Waltham, San Diego: Academic Press, Elsevier.

De Smet, A., Schaninger, B. \& Loch, M. (2007). Anatomy of a healthy corporation. The McKinsey Quarterly, 3, 64.

DeVellis, R.F. (2003). Scale Development: Theory and Applications. Thousand Oaks, London, New Delhi: Sage Publications.

Di Stefano, G., Peteraf, M., \& Verona, G. (2009). Dynamic capabilities deconstructed. Paper presented at the Annual Conference Academy of Management in Chicago.

Drazin, R., Glynn, M.A. \& Kazanjian, R.K. (1999). Multilevel theorizing about creativity in organizations: A sensemaking perspective. Academy of Management Review, 24(2), 286-307. 
Ezzamel, M. \& Willmott, H. (2008). Strategy as discourse in a global retailer: A supplement to rationalist and interpretive accounts. Organization Studies, 29(2), 191-217.

Ferris, G.R. \& Hochwarter, W.A. (2011). Organizational politics. In: S. Zedeck (ed.), APA Handbook of Industrial and Organizational Psychology (Vol. 3, pp. 435-459). Washington, DC: American Psychological Association.

Ferris, G.R. \& Treadway, D.C. (2012). Politics in Organizations: Theory and Research Considerations. New York, Hove: Routledge.

Foucault, M. (1977). History of systems of thought. In: D.F. Bouchard (ed.), Language, Counter-Memory, Practice (pp. 199-204). New York: Cornell University Press.

Foucault, M. (1978). The History of Sexuality, Vol. 1: An Introduction. Harmondsworth: The Penguin.

Gioia, D.A. \& Chittipeddi, K. (1991). Sensemaking and sensegiving in strategic change initiation. Strategic Management Journal, 12(6), 433-448.

Greve, H.R. \& Mitsuhashi, H. (2007). Power and glory: Concentrated power in top management teams. Organization Studies, 28(8), 1197-1221.

Halford, S. \& Leonard, P. (2006). Place, space and time: Contextualizing workplace subjectivities. Organization Studies, 27(5), 657-676.

Hardy, C. \& Thomas, R. (2012). Strategy, discourse and practice: The intensification of power. Journal of Management Studies, 51(2), 320-348.

Hope, O. (2010). The politics of middle management sensemaking and sensegiving. Journal of Change Management, 10(2), 195-215.

Jarzabkowski, P. (2005). Strategy as Practice: An Activity Based Approach. London: Sage.

Jay, J. (2013). Navigating paradox as a mechanism of change and innovation in hybrid organizations. Academy of Management Journal, 56(1), 137-159.

Kanter, R.M. \& Stein, B.A. (1992). Challenge of Organizational Change. New York: The Free Press.

Kreiser, P., Kuratko, D.F., Covin, J.G. \& House, M. (2011). Operationalizing corporate entrepreneurship strategy (CES): A configurational approach. The paper presented at the Annual Conference Academy of Management in San Antonio.

Laine, P.-M. \& Vaara, E. (2007). Struggling over subjectivity: A discursive analysis of strategic development in an engineering group. Human Relations, 60(1), $29-58$.

Leon-Guerrero, A. \& Frankfort-Nachmias, C. (2015). Essentials of Social Statistics for a Diverse Society ( $2^{\text {nd }}$ edition). Los Angeles, London, New Delhi, Singapore, Washington DC: Sage Publications.

Maitlis, S. \& Lawrence, T.B. (2007). Triggers and enablers of sensegiving in organizations. Academy of Management Journal, 50(1), 57-84. 
Mantere, S., Schildt, H.A. \& Sillince, J.A. (2012). Reversal of strategic change. Academy of Management Journal, 55(1), 172-196.

McCabe, D. (2010). Strategy-as-power: Ambiguity, contradiction and the exercise of power in a UK building society. Organization, 17(2), 151-175.

McKinlay, A., Carter, C., Pezet, E. \& Clegg, S. (2010). Using Foucault to make strategy. Accounting, Auditing \& Accountability Journal, 23(8), 1012-1031.

Miller, B.K., Rutherford, M.A. \& Kolodinsky, R.W. (2008). Perceptions of organizational politics: A meta-analysis of outcomes. Journal of Business and Psychology, 22(3), 209-222.

Oliver, C. \& Holzinger, I. (2008). The effectiveness of strategic political management: A dynamic capabilities framework. Academy of Management Review, 33(2), 496-520.

Podsakoff, N.P., Shen, W. \& Podsakoff, P.M. (2006). The role of formative measurement models in strategic management research: review, critique, and implications for future research. In: A. Ketchen \& D.D. Bergh (eds.), Research Methodology in Strategy and Management (Vol. 3, pp. 197-252). Emerald Group Publishing Limited.

Rasche, A. \& Chia, R. (2009). Researching strategy practices: A genealogical social theory perspective. Organization Studies, 30(7), 713-734.

Rudolph, J.W., Morrison, J.B. \& Carroll, J.S. (2009). The dynamics of action-oriented problem solving: Linking interpretation and choice. Academy of Management Review, 34(4), 733-756.

Sederberg, P.C. (1984). The Politics of Meaning Power and Explanation in the Construction of Social Reality. Tucson: University of Arizona Press.

Sharfman, M.P. \& Dean Jr, J.W. (1991). Conceptualizing and measuring the organizational environment: A multidimensional approach. Journal of Management, 17(4), 681-700.

Silvester, J. (2008). The good, the bad and the ugly: Politics and politicians at work. International Review of Industrial and Organizational Psychology, 23, 107.

Sonaike, K. (2013). Revisiting the good and bad sides of organizational politics. Journal of Business \& Economics Research (Online), 11(4), 197-202.

Sonenshein, S. (2010). We're changing - or are we? Untangling the role of progressive, regressive, and stability narratives during strategic change implementation. Academy of Management Journal, 53(3), 477-512.

Stańczyk-Hugiet, E. (2014). Pola eksploracji Strategy as Practice International Network. In: R. Krupski (ed.), Zarzqdzanie strategiczne. Rozwój koncepcji i metod (pp. 85-99). Wałbrzych: Wydawnictwo Wałbrzyskiej Wyższej Szkoły Zarządzania i Przedsiębiorczości w Wałbrzychu.

Vaara, E. \& Whittington, R. (2012). Strategy-as-practice: Taking social practices seriously. Academy of Management Annals, 6(1), 285-336. 
Weick, K.E. (1988). Enacted sensemaking in crisis situations. Journal of Management Studies, 25(4), 305-317.

Wood, R.C. (2007). How strategic innovation really gets started. Strategy \& Leadership, 35(1), 21-29.

Zbierowski, P., Bratnicka, K., \& Dyduch, W. (2014). Organizational positivity, high performance factors, creativity and creative strategy as antecedents of competitive advantage. The paper presented at the Annual Conference British Academy of Management in Belfast. 


\section{POLITYKOWANIE ORGANIZACYJNE I ZMIANA: MODEL KONCEPCYJNY I JEGO EMPIRYCZNE SPRAWDZENIE}

Przedsiębiorstwa coraz częściej biora pod uwage politykowanie organizacyjne jako kluczowy wymiar zarządzania zmianami organizacyjnymi. Dążąc do lepszego zrozumienia tych procesów, zbudowałam i sprawdziłam empirycznie konceptualny model, wykorzystując $\mathrm{w}$ tym celu dane empiryczne pozyskane ze 158 małych i średnich polskich przedsiębiorstw. Wyniki tych badań wyjaśniają wzajemne powiązania między politykowaniem organizacyjnym, zarządzaniem zmianami organizacyjnymi i efektywnością organizacyjna. W rezultacie poszerzono i uszczegółowiono zrozumienie roli politykowania organizacyjnego jako nośnika powodzenia zmiany organizacyjnej.

Słowa kluczowe: politykowanie organizacyjne, zarządzanie zmianami organizacyjnymi, efektywność organizacyjna. 